\title{
ENHANCING WRITING SKILL THROUGH WRITING PROCESS APPROACH
}

\author{
M. Zaini Miftah \\ IAIN Palangka Raya \\ miftahmzaini@gmail.com
}

\begin{abstract}
The study is aimed at developing the implementation of Writing Process Approach (WPA) to enhance the students' skill in writing essay. The study employed Classroom Action Research. The subjects of the study were 15 university students enrolled in the writing class. The data were gained from writing task, observation and field notes. The findings show that the implementation of WPA with the proper model procedures developed can enhance the students' skill in writing essay. Before the strategy was implemented, the percentage of the students achieving the score greater than or equal to C (56-70) was $40.00 \%$ (6 students of the class). However, after the strategy was implemented in Cycle I, it enhanced enough to $60.00 \%$ (9 students of the class), but this result did not meet the criteria of success set up in the study. Next, in Cycle II it increased slightly to $86.67 \%$ (13 students of the class). Thus, the enhancement of the students' skill in writing essay can be reached but it should follow the proper model procedures of the implementation of WPA developed.
\end{abstract}

Keywords: writing process approach, writing skill, essay writing

Learning a second language means learning to communicate with other people to understand them, talk to them, read what they have written and write to them (Raimes, 1983:3). Writing as one of the skills to communicate is not an ability we acquire naturally; even in our first language it has to be taught. However, writing is not interesting for most EFL (English as a Foreign Language) students.

Writing is considered as the most difficult and complicated language skill to be learned compared to other language skills - listening, speaking and reading. It requires more effort to produce meaning through writing than to recognize meaning through listening and reading (Dixon \& Nessel, 1983). In fact, Nunan (1999:271) considers it as an enormous challenge to produce "a coherent, fluent, extended piece of writing" in one's second language. This is magnified by the fact that the rhetorical conventions of English texts - the structure, style and organization - often differ from the convention in other languages. It requires effort to recognize and manage the differences (Leki, 1991).

In relation to the students' difficulties in writing, Mukminatien (1991) asserts that the difficulties are not merely caused by the students' themselves but they can also be caused by the unvaried and uninteresting techniques of the lecturers in teaching writing. These will result their boredom and less motivation in learning it. Consequently, writing is not a favorite course, for neither the students nor the lecturers.

The lecturers' techniques in teaching writing not varied and not interesting can also cause difficulties for the students to learn how to write a piece of writing. Gebhard (2000:235) explains 
that there are some problems faced by EFL lecturers in the writing instruction. First of all is the problem of teaching, the less proficient writers who tend to use ineffective strategies of writing. In this case, the lecturers should give more attention to them to show how to plan and produce a piece of writing. The second one is dealing with the lecturers' response. The students generally do not pay attention to the lecturers' comments and corrections to their written work. Consequently, the lecturers should find an effective way of building students' self confidence by which they can change their negative attitude towards writing activities.

In accordance with the problems indicated above, the problems also happened to the researcher as an English lecturer. He faced the same problems in teaching writing in the classroom. His experience as an English lecturer of the third-semester students of English Education Department of STIT Maskumambang Gresik shows that the students' writing skill in English is still low. Their writings had many mistakes in terms of content, organization and grammar. It is supported by the preliminary study conducted on the $5^{\text {th }}$ and $12^{\text {th }}$ of December 2009. The percentage of the students' score obtained from the fifteen students' writing tasks was that $6.67 \%$ (1 student) got score A, 13.33\% (2 students) got score B, $20.00 \%$ (3 students) got score $C$, and $60.00 \%$ (9 students) got score $\mathrm{D}$. These results are considered to be insufficient since majority of the students were unsuccessful in this course. Only $40 \%$ (6 students of the class) achieved the score greater than or equal to C (56-70). It did not yet achieve the target of the study of the Writing-III Course at the university. It must at least get score C (56-70) for majority of the students for the Writing-III Course success as stated in the guideline of scoring at the university.

Additionally, the researcher has also observed that there are some problems that need to overcome. He found some problems in the writing class; the students had never expressed their ideas in the process of producing essay using systematic stages, the piece of the writings they produced had many grammatical inaccuracies, the English instruction was not focused since the students were just given tasks based on the textbook without expressing their ideas based on their context, they had difficulties to produce a unified essay so that it was not easy to understand, most of the sentences of the paragraphs and the paragraphs of the essay were not related to the main idea and not logically ordered, and the students did not have strong motivation and were not interested in the writing class so they just kept silent and looked confused when the lecturer asked them to do the tasks.

Those problems are caused by a number of factors; in teaching writing the lecturer assigns the students to write an essay without guiding them in the process of writing so they have never expressed their ideas in the process of producing essay using systematic stages (the writing activities done by the students are only product oriented), the lecturer does not give a model of writing to write an essay making the students know what to do for writing, the lecturer has never held a conference with their students to discuss the stages they did in producing a piece of writing and help them to identify the 
errors and mistakes they made for improvement in writing, the lecturer does not provide a model of essay organization of various types of essays stated in the syllabus of the Writing-III Course at the university, the lecturer does not try to find out appropriate techniques or strategies in teaching writing, and the material conveyed to the students is not related to the real life so that it is so far from their context. Consequently, the students feel bored and are not interested in doing the tasks, so their ability in constructing and composing their own essays is still low.

In response to the fore-mentioned problems faced by the students, the study was focused on solving the problem related to how the students express their ideas in the process of producing essay systematically. It tended to be the urgent problem to solve, since in the writing process, the lecturers' role is to provide guidance for the students to go through the process of writing with the interesting and challenging activities. They are encouraged to have students work through a process of prewriting then drafting, revising, editing and publishing (Tompkins \& Hoskisson, 1995).

Regarding the problem to solve, the researcher proposed the implementation of Writing Process Approach (WPA) with the proper model procedures developed. He believes that the strategy seemed to be applicable in teaching writing. It could hopefully overcome the students' problem especially in term of how they express their ideas in the process of producing essay systematically and enhance their writing skill.

Smalley et al. (2001) stated that WPA can give a positive impact on students' motivation in both studying
English and developing their writing skill. It means that WPA can encourage students to write even in cases where they may initially be afraid of doing so, for example, fear of making errors. Besides, it can also set and increase the students' selfconfidence, interest, and self-esteem because they can go through the stages of the process which are not rigid. Students can move back and forth between the stages, perhaps going back to the prewriting stage to add some more materials after revising or rewriting a paragraph they have just drafted.

In addition, the approach can also make the students more involved by actively participating in the learning process leading to understanding. So they can make sense of the writing activities in their real life and be more motivated as well. As added by Brown (2001:348), WPA tends to be framed in terms of prewriting, drafting, and revising stages.

In relation to research implementing WPA in teaching writing, a study had been conducted. Ndanguru (2008) did a study trying to solve the students' problem in writing recount paragraphs by implementing WPA. The finding showed that by implementing it, the students' writing ability had increased. In the present study, the researcher attempts to overcome his problems in writing class faced by the students related to how they express their ideas in the process of producing essay systematically. Therefore, it was very much necessary to conduct a study to enhance the skill of the third-semester students of English Education Department of STIT Maskumambang Gresik in writing essay. The researcher tried to develop the 
proper model procedures of the implementation of WPA applicable in the writing instruction at the university.

Based on the background of the study, the research problem is: "How can WPA be implemented to enhance the students' skill in writing descriptive essay?" Meanwhile, this study aims at developing the implementation of WPA to enhance the students' skill in writing descriptive essay.

The study centered on developing the implementation of WPA to solve the problem of how the students express their ideas in the process of producing essay systematically. Regarding the assessment, this study focused upon the components of writing - content, organization and grammar. Those three aspects are paramount importance to assess because they can establish the quality of the writing. Content is the substance and the essence of writing. It is the heart-beat of any great writing. To develop the paragraphs students soundly organize the specific facts and ideas, and require grammar for making sentences (Onukwugha, 2007).

Meanwhile, since the implementation of WPA in this study was centered on enhancing the skill of the third-semester students of English Education Department of STIT Maskumambang Gresik in writing essay in the $2009 / 2010$ academic year, the type of essay was limited to descriptive essay as provided in the syllabus of Writing-III Course at the university. Besides, most of the students still got difficult to write descriptive essay. When they were given the task of writing descriptive essay, about $40.00 \%$ or 6 students of the class achieved the score greater than or equal to
C (56-70). Thus, the score obtained from their writing tasks was still low.

The study was expected to give meaningful contributions to both the students and the English lecturers lecturers of Writing Course. It was expected that the students will implement WPA with the proper model procedures developed to express their ideas in the process of producing essay systematically in writing classes so that they will become more motivated in doing writing tasks. To the English lecturers, it can hopefully solve the problem in their writing teaching and enable them to enhance the students' skill in writing essay.

\section{METHOD}

The study employed Classroom Action Research which is conducted in cyclic activities (Kemmis \& McTaggart, 1992) - planning, implementing, observing and reflecting on the data gained from the teaching and learning process - which run into two cycles, each of which covers three meetings. The subjects of the study were the thirdsemester students inrolled in the English Education Department of STIT Maskumambang Gresik in the 2009/2010 academic year. The numbers of subjects were 15 students taking a Writing-III Course.

In implementing the action, it was decided that the researcher acted as the lecturer conducting instruction process in the class. Meanwhile, his collaborator acted as an observer observing the activities and performance during the implementation of the action. In analyzing the data, the researcher analyzed them based on two classifications. 
The data dealing with the students' writing achievement were analyzed by utilizing the analytic scoring rubric adapted from Cohen (1994:328-329). Their individual score was obtained from the sum of scores from each component obtained by the student, while the mean of the students' score was obtained from the sum of the student's individual score divided by the number of the students.

Besides, the students' writings were analyzed and scored by the researcher (rater 1) and his collaborator (rater 2) independently to avoid the subjectivity of the gained scores. It was conducted to know reliability of the test. Reliability of the test of writing ability test can be gained from two rows of score taken by two raters from the students' work (Djiwandono, 2008:186). In this study rater reliability (inter-rater reliability) was applied. Next, the student's final writing score was obtained from the mean score of their individual score taken by rater 1 and rater 2. The results of the analysis were then presented quantitatively in the form of number as shown in Table 1 and 2 . Additionally, the proof of validity empirically was done by presenting the empiric evidence gained from the result of correlation computation of two rows of score taken by two raters. So the correlation of Pearson product-moment is used to find the correlation coefficient (Djiwandono, 2008: 167).

The data dealing with the students' involvement in the writing activities gathered through observation checklist were analyzed quantitatively based on the number of the scale checked by the observer in the observation checklist. The percentage of the students doing the activities was gained from the mean of total students doing the activities divided by the student number of the whole class and then multiplied by one hundred. The results of the analysis were next presented quantitatively (Table 3) as well as qualitatively by interpreting the number of percentage gained. In addition, the data-gathering through field notes were analyzed and then merely presented descriptively by presenting the description of the teaching and learning process.

The results of all the analyses, furthermore, were employed to decide whether the predetermined criteria of success met or not. The result of this reflection was then used as the basic consideration to draw a conclusion whether the action stopped or needed improving. If the action met the criteria of success, it stopped. Otherwise, the drawbacks were identified for further revised plan and then implemented it in the next cycle.

\section{FINDINGS FROM CYCLE I}

\section{The Students' Achievement}

Based on the analysis on the students' compositions in Cycle I as shown in Table 1, the findings show that the students' achievement in writing a descriptive essay in Cycle I was not satisfactory yet. It was found that the percentage of the students achieving the score greater than or equal to $C$ (56-70) was only $60.00 \%$ (9 students of the class). This percentage was greater than those obtained from the writing tasks in Preliminary Study $(40.00 \%$ or 6 students of the class). From those findings, it means that the students' achievement in writing a descriptive essay in Cycle I enhanced 
enough but it did not meet the first criterion of success. It was stated that the criterion was reached if $\geq 75 \%$ students of the class achieved the score greater than or equal to $C$ (56-70) of the range that lies from 0-100.

The students' unsatisfactory writing achievement happened because most of the students still could not yet produce a good descriptive essay. They were still difficult to express their ideas in the process of producing the essay through the writing process such as prewriting, drafting, revising, editing and publishing. The fact showed that the students' essays were not complete with details yet. There were still many mistakes made by the students in their writings. The results of the writing assessment administrated showed that the students still made some mistakes in terms of content, organization and grammar.

Most of the students' writings did not present some details information yet. The thesis sentence or main ideas of their essays stated somewhat unclear or inaccurate and some others stated clear or accurate. Their writings were organized with ideas generally related but it did not have sentence connectors while some others were loosely organized but main ideas clear, logical, but incomplete sequencing. Besides, their writings still contained grammatical mistakes. The mistakes made by the students made their writings not easy to understand.

\section{The Students' Involvement}

Based on the result of analysis on the data gained from the observation checklist in Cycle I as shown in Table 3, the findings show that the students' involvement in the writing activities was categorized as good. It was found that the average percentage of the students doing the activities was $66.67 \%$ (10 students of the class were actively involved in the writing activities). Even though it was categorized as good, the result was still fail since it did not meet the second criterion of success. It was stated that the criterion was reached if the students' involvement during the implementation of strategy in the writing activities was categorized as very good (76\%-100\% students of the class or 12-15 students did the activity).

It happened since during the instruction process in the three meetings, the students faced the trend problems. Most of the students had problems of how to write first draft since they had insufficient background knowledge of the topic they were going to write. The students still did not understand how to write first draft up to write final version. In other word, some students still got difficulties of what to do in every writing stage. In addition, they could not differentiate between the activities done in revising and editing stages.

\section{Revision on the Strategy}

Some modifications for the following action had made. It was centered on the procedures of implementing the action in order to find the proper model procedures of WPA which were applicable in the writing class. The followings are the model procedures implemented in the next Cycle. 
Table 1. The Result of Analysis on the Students' Compositions in Cycle I

\begin{tabular}{cccccc}
\hline No & Students & SIS-1 & SIS-2 & \multicolumn{2}{c}{$\begin{array}{c}\text { Students' } \\
\text { Final Score }\end{array}$} \\
\hline 1 & AM & 77,0 & 84,5 & 80,8 & $\mathrm{~B}$ \\
\hline 2 & EK & 69,5 & 69,5 & 69,5 & $\mathrm{C}$ \\
\hline 3 & FIR & 54,0 & 54,0 & 54,0 & $\mathrm{D}$ \\
\hline 4 & HN & 69,5 & 77,0 & 73,3 & $\mathrm{~B}$ \\
\hline 5 & IA & 54,0 & 46,0 & 50,0 & $\mathrm{D}$ \\
\hline 6 & KU & 69,0 & 61,5 & 65,3 & $\mathrm{C}$ \\
\hline 7 & MAS & 54,0 & 69,5 & 61,8 & $\mathrm{C}$ \\
\hline 8 & MA & 85.5 & 85.5 & 85.5 & $\mathrm{~A}$ \\
\hline 9 & ND & 38,5 & 61,5 & 50,0 & $\mathrm{D}$ \\
\hline 10 & NA & 61,5 & 69,5 & 65,5 & $\mathrm{C}$ \\
\hline 11 & SA & 53,5 & 54,0 & 53,8 & $\mathrm{D}$ \\
\hline 12 & SW & 46,0 & 61,5 & 53,8 & $\mathrm{D}$ \\
\hline 13 & MS & 77,0 & 77,0 & 77,0 & $\mathrm{~B}$ \\
\hline 14 & SUY & 54,0 & 54,0 & 54,0 & $\mathrm{D}$ \\
\hline 15 & US & 85,0 & 92,5 & 88,8 & $\mathrm{~A}$ \\
\hline
\end{tabular}$* 8$

Note: SIS-1 : Student's Individual Score taken by Rater 1

SIS-2 : Student's Individual Score taken by Rater 2

In Cycle I, the percentage of the students achieving the score greater than or equal to $C$ (56-70) was $\mathbf{6 0 . 0 0 \%}$ (9 students) *

The first step, when the lecturer assigned the students to write first draft, he called their background knowledge of the topic of essay they were going to write. He provided them with the pictures through LCD as a brainstorming. He also questioned the students about what were in the pictures and what was the topic discussed. Then he guided them to make a clustering of ideas generated. Why the researcher did those since in Cycle I the lecturer did not provide them when conducted brainstorming. The pictures were given only small pictures. Also the lecturer's questions did not focus on the topic. By providing picture through LCD and questions focusing on the topic, it hopefully made the students easier to find ideas and pour them in a clustering. Thus, in drafting stage, the activity was referred to the prewriting activity and the students' drafts were more suitable with their ideas in the map they had made.

The second one, the lecturer clarified his explanation by describing the strange words or sentences clearly and repeatedly when some students looked confused to interest them and to avoid miscommunication. He fully helped them until they really understood the strange words. It was done in every writing stage.

The next step, the lecturer provided the students with models of the rough draft and guideline of doing drafting, revising and editing activities individually. By this emphasis, the students were expected to be more serious and active to do the tasks. It also made 
them more guided, more responsible and easier to do the tasks.

Then, the lecturer equipped them with vocabulary guide related to the topic of the lesson as the initial language input to do the task in every writing stage continuously. It aimed at helping the students to solve their problem of the vocabulary mastery. It also supported them in order that they could write essay fast.

After that, the lecturer assigned the students to do the tasks individually in every writing stage while they worked cooperatively in a group. It was done to support them to be active in doing the task since it was finally expected that they could produce their individual essay. Also, he could control their individual works.

The last one, the lecturer provided the students some more chances to do proofreading, peer editing, and sharing their writings in conferences. It was maximally done through monitoring the students' activities on the task and walking around the class using time effectively. So, they were expected to be more actively involved in those activities.

\section{FINDINGS FROM CYCLE II}

\section{The Students' Achievement}

Based on the analysis on the students' compositions in Cycle II as shown in Table 2, the findings show that the percentage of the students achieving the score greater than or equal to $C$ (56-70) was $86.67 \%$ (13 students of the class). This percentage was greater than those obtained from Cycle I $(60.00 \%$ or 9 students of the class). From these findings, it means that the students' achievement in writing a descriptive essay in Cycle II enhanced and it met the first criterion of success. It was stated that that the criterion was reached if $\geq 75 \%$ students of the class achieved the score greater than or equal to $C(56-70)$ of the range that lies from 0-100.

Even though the students' achievement in writing enhanced, it was still found the certain types of mistakes made by the students in their essays. The number of the mistakes had begun reducing. It seemed that the students doing some mistakes were those who were categorized as the students of the lower of English. Most of the students' writings presented more details information and the thesis sentence or main ideas of their essays stated fairly, clearly and accurately. Also, most of their essays were fairly well organized and generally coherent but their writings still contained some grammatical mistakes. Even though some students could not yet revise their inappropriate sentences and paragraphs, their writings had already improved. In the writing activities, the students could express their ideas in the process of producing essay systematically through prewriting, drafting, revising, editing and publishing. The fact shows that they could produce descriptive essays dealing with describing the place 'Ramayana Book Store'. Thus, their descriptive essays were already understandable and readable. 
Table 2. The Result of Analysis on the Students' Compositions in Cycle II

\begin{tabular}{|c|c|c|c|c|c|}
\hline No & Students & SIS-1 & SIS-2 & \multicolumn{2}{|c|}{$\begin{array}{l}\text { Students' } \\
\text { Final Score }\end{array}$} \\
\hline 1 & $\mathrm{AM}$ & 85.5 & 85.5 & 85.5 & $\mathrm{~A}$ \\
\hline 2 & EK & 69,5 & 77,0 & 73,3 & $\mathrm{~B}$ \\
\hline 3 & FIR & 54,0 & 54,0 & 54,0 & $\mathrm{D}$ \\
\hline 4 & $\mathrm{HN}$ & 77,0 & 77,0 & 77,0 & B \\
\hline 5 & IA & 69,0 & 61,5 & 65,3 & $\mathrm{C}$ \\
\hline 6 & KU & 69,5 & 69,5 & 69,5 & $C$ \\
\hline 7 & MAS & 69,0 & 77,0 & 73,0 & $\mathrm{~B}$ \\
\hline 8 & MA & 85,0 & 92,5 & 88,8 & A \\
\hline 9 & ND & 54,0 & 69,5 & 61,8 & $C$ \\
\hline 10 & NA & 77,0 & 77,0 & 77,0 & $\mathrm{~B}$ \\
\hline 11 & SA & 54,0 & 54,0 & 54,0 & $\mathrm{D}$ \\
\hline 12 & SW & 61,5 & 69,5 & 65,5 & $\mathrm{C}$ \\
\hline 13 & MS & 85,0 & 77,0 & 81,0 & $\mathrm{~B}$ \\
\hline 14 & SUY & 61,5 & 77,0 & 69,3 & $\mathrm{C}$ \\
\hline 15 & US & 92,5 & 88.8 & 90.65 & A \\
\hline
\end{tabular}

Note: SIS-1 : Student's Individual Score taken by Rater 1

SIS-2 : Student's Individual Score taken by Rater 2

(อ)In Cycle II, the percentage of the students achieving the score greater than or equal to $C(56-70)$ was $\mathbf{8 6 . 6 7 \%}$ (13 students) *

\section{The Students' Involvement}

Based on the result of analysis on the data gained from the observation checklist in Cycle II as shown in Table 3, it was found that the average percentage of the students doing the activities was $93.33 \%$ (14 students of the class were actively involved in the writing activities). This result was greater than those gained from Cycle I $(66.67 \%$ students or 10 students of the class). It means that the students' involvement in the writing activities was categorized as very good and it met the criterion of success. It was stated that the criterion was reached if the students' involvement in the writing activities was categorized as very good (76\%-100\% students of the class or $12-15$ students did the activity).

\section{DISCUSSIONS}

The Procedures Employed in Implementing WPA

Based on the research findings, the implementation of WPA can enhance the students' skill in writing a descriptive essay. Although all students have not achieved the maximum results, most of their writing skills have enhanced as shown in the results of the assessment in each cycle (Table 1 and 2 ). 
Table 3. The Result of Analysis on the Data Gained from Observation

\begin{tabular}{|c|c|c|c|c|}
\hline \multirow[t]{2}{*}{ Meeting } & \multirow{2}{*}{$\begin{array}{l}\text { Writing } \\
\text { Stages }\end{array}$} & \multirow[t]{2}{*}{ Description of Students' Activities } & \multicolumn{2}{|c|}{$\begin{array}{c}\text { Progress } \\
\text { Percentages }\end{array}$} \\
\hline & & & Cycle I & Cycle II \\
\hline \multirow{9}{*}{1} & \multirow{9}{*}{$\begin{array}{c}\text { Prewriting } \\
+ \\
\text { Drafting }\end{array}$} & 1. Paying attention to the teacher's instruction. & $66.67 \%$ & $93.33 \%$ \\
\hline & & 2. Responding to the teacher's instruction. & $66.67 \%$ & $100 \%$ \\
\hline & & 3. Contributing ideas for the topic. & $46.67 \%$ & $73.33 \%$ \\
\hline & & 4. Generating and organizing ideas. & $73.33 \%$ & $100 \%$ \\
\hline & & 5. Writing rough drafts based on generated ideas. & $53.33 \%$ & $93.33 \%$ \\
\hline & & 6. Writing a thesis sentence of essay. & $93.33 \%$ & $93.33 \%$ \\
\hline & & 7. Writing supporting paragraphs. & $60.00 \%$ & $73.33 \%$ \\
\hline & & $\begin{array}{l}\text { 8. Using the generic structure of descriptive text } \\
\text { in the rough drafts. }\end{array}$ & $73.33 \%$ & $100 \%$ \\
\hline & & $\begin{array}{l}\text { 9. Placing a greater emphasis on content and } \\
\text { organization than on mechanics in the rough } \\
\text { drafts. }\end{array}$ & $46.67 \%$ & $73.33 \%$ \\
\hline & & Mean 1 & $66.67 \%$ & $93.33 \%$ \\
\hline \multirow{4}{*}{2} & \multirow{4}{*}{ Revising } & 10. Sharing their writings in conferences. & $46.67 \%$ & $73.33 \%$ \\
\hline & & $\begin{array}{l}\text { 11. Participating in discussions about classmates' } \\
\text { writings. }\end{array}$ & $66.67 \%$ & $93.33 \%$ \\
\hline & & $\begin{array}{l}\text { 12. Making changes to reflect the reactions and } \\
\text { comments of both teacher and classmates. }\end{array}$ & $60.00 \%$ & $73.33 \%$ \\
\hline & & $\begin{array}{l}\text { 13. Making substantive changes between first and } \\
\text { second drafts. }\end{array}$ & $73.33 \%$ & $100 \%$ \\
\hline & & Mean 2 & $60.00 \%$ & $86.67 \%$ \\
\hline \multirow{7}{*}{3} & \multirow{5}{*}{$\begin{array}{c}\text { Editing } \\
+ \\
\text { Publishing }\end{array}$} & 14. Proofreading their own papers. & $66.67 \%$ & $73.33 \%$ \\
\hline & & 15. Helping proofread classmates' papers. & $46.67 \%$ & $73.33 \%$ \\
\hline & & $\begin{array}{l}\text { 16. Editing and polishing their works by } \\
\text { correcting errors in spelling, grammar, and } \\
\text { punctuation. }\end{array}$ & $73.33 \%$ & $100 \%$ \\
\hline & & 17. Writing the final writing version. & $93.33 \%$ & $100 \%$ \\
\hline & & $\begin{array}{l}\text { 18. Sharing their final writings with the other } \\
\text { students by reading them aloud to the whole } \\
\text { class or in a small group or a partner }\end{array}$ & $73.33 \%$ & $100 \%$ \\
\hline & & Mean 3 & $73.33 \%$ & $93.33 \%$ \\
\hline & & Mean $(1+2+3)$ & $66.67 \%$ & $93.33 \%$ \\
\hline
\end{tabular}

Adapted from Tompkins $\mathcal{E}$ Hoskisson (1995: 231)

Note:

Number of students: 15

Scale: 1 (poor) : :0\%-25\% students do the activities

2 (fair) : $26 \%-50 \%$ students do the activities

(0-3 students) $\quad \sigma$ fail

3 (good) : $51 \%-75 \%$ students do the activities

(4-7 students) $\quad \sigma$ fail

4 (very good) : $76 \%-100 \%$ students do the activities (12-15 students)

$\sigma$ fail

or succeed 
$\sigma$ In Cycle I, the average percentage of the students doing the activities is $\mathbf{6 6 . 6 7 \%}$ (10 students) categorized as good (fail).

$\checkmark$ In Cycle II, the average percentage of the students doing the activities is $\mathbf{9 3 . 3 3 \%}$ (14 students) categorized as very good (succeed).

Regarding the above description, it seems that the students are able to communicate by using written language in which they do all of the activities provided by the lecturer during the process of the action cycles. Those activities are related to the procedures employed in writing a descriptive essay that may enhance their writing skill. The proper model procedures of the implementation of WPA developed by the lecturer for writing activities involves the application of the writing stages adapted from Tompkins \& Hoskisson (1995), those are, prewriting, drafting, revising, editing and publishing. The application of the writing stages is as follows.

Prewriting stage focuses on brainstorming. Prewriting is a preparation to write and the getting-ready-to-write stage which is like a warming-up for the athletes (Tompkins \& Hoskisson, 1995: 211). It was meant to help students to collect ideas, viewpoints, or ideas related to the topic being discussed. This was in line with Gebhard (2000) stating that brainstorming is an activity in which the students call out ideas associated with the topic while the teacher (or a student or two) write ideas on the board. It is also supported by Raimes (1983) pointing out that brainstorming is an activity to produce words, phrases, ideas as rapidly as possible without concerning for appropriateness, order or accuracy. In this brainstorming the lecturer applied visual media, pictures related to the topic discussed, through LCD. It was to call the students' background knowledge related to the topic they were going to write. He also questioned the students about what were in the pictures and what was the topic discussed. He then employed the technique of clustering. He asked the students to write the topic or concept in the middle of paper then drew a line out from the circle and wrote an idea associated with the topic. After that, they continued mapping their ideas and making relationship between an idea and other one as many as the students could think of.

Drafting stage centers on providing the students chances to start writing based on mapped idea they had made in the previous stage. Drafting is a stage designed to allow the writers to put their ideas on paper without worrying about mechanics or neatness (Roe et al., 1995). This statement is in line with Christenson (2002: 41) asserting that drafting is the process of getting ideas on paper and Brown (2001) pointing out that "drafting is viewed as an important and complex set of strategies, the mastery of which takes time, patience and trained instruction." Besides, Brown (2001: 347) states that by reading and studying a variety of relevant model of texts, students can gain important insight both about how they should write about subject matter that they may become the topic of their writing. In this stage, the students were assigned to write rough draft as their first draft. 
The lecturer gave a model of descriptive essay and then followed by the explanation before having students write their first draft. To guide the students how to do drafting, the lecturer guided them to check a model of rough draft step-by-step by using drafting guidelines. The students were assigned to check the draft whether (1) the essay contained text organization (identification) or not, (2) the essay contained text organization (descriptions), and (3) the essay contained language features (the use of simple present form, adjectives, verb be, have, look, seem, etc.) or not.

Revising stage focuses on providing the students chances to revise their first draft they had made in the drafting stage with emphasis on the content and organization rather than on the mechanics. Revising is to make the writing clearer and more interesting to the readers (Glencoe, 2001:58). Both drafting and revising stages are the core of the writing process (Brown, 2001:348).

In revising stage students rethink and rewrite the first draft to form the second draft. The students were guided to revise a model of rough draft step-by-step. The students were assigned to check the draft whether (1) the essay had thesis sentence or not and each paragraph had topic sentence or not, (2) the thesis sentence of the essay and the topic sentence of each paragraph were clear or not, (3) all the supporting paragraphs referred to the thesis sentence or not, (4) all of the sentences of each paragraph and the paragraphs were well organized or not, (5) the paragraphs used sentence connectors or not, and (6) the first sentence of each paragraph is indented or not.
Editing stage centers on providing the students chances to edit the drafts, and proofread the drafts for accuracy and correctness in spelling, punctuation, capitalization and grammar. Editing is putting the piece of writing into its final form. It is the process in which the students begin to look at correctness (Stone, 1990). Tompkins \& Hoskisson (1995) assert that the editing stage primarily focuses on the content of students' writing. The students need to edit their draft to make sure their sentences are clear (Glencoe, 2001:71).

In this stage the students were guided to edit a model of rough draft step-by-step through editing guidelines. The students were assigned to answer the questions provided step by step. The students were asked to check the draft whether (1) each paragraph used the correct tense or not, (2) all the subjects and verbs are agreed or not, (3) all the sentences used correct word order or not, (4) the sentences used correct plural form or not, (5) the first letter of each sentence was capitalized or not, (6) the first letter of the proper nouns was also capitalized or not, (7) each sentence used punctuation correctly or not, and (8) all words were spelled correctly or not.

Additionally, in editing stage the students were assigned to edit their friends' drafts in terms of the spelling, punctuation and grammar. This is supported by Stone (1990) pointing out that the editing is the stage of the writing process in which students begin look at correctness. Besides, they were also assigned to have a mini-conference with the lecturer. It was done by discussing the students' writing with the lecturer individually. This statement is in line with 
Church's statement in O'Malley \& Pierce (1996). It is stated that conferencing is an important component of the writing process in which the lecturer meets with the students individually and asks questions about the process they use in writing. The findings showed that having mini-conference could give a positive impact on the students' drafts. At first, the students were reluctant to come to the lecturer's and collaborator's tables, but later on they enjoyed the activities very much. As the result, most of the students could work cooperatively by giving comment or suggestion although it was still in simple one.

The last stage was publishing stage. In this stage the students were given a chance to publish their final compositions. The publishing activities could be done by asking students to read his/her own writing in front of the class or by asking the students to read their friends' final writing. Those statements are in line with Kirby \& Liner's in Vacca \& Vacca (1998). It is asserted that publishing is a form of activity that is very important for students as it provides an opportunity for them to share their writing product with real audience of their classmates and other students. In addition, Tompkins (1994) proposed some ways to share children's writing such as reading it aloud in class, displaying it on bulletin board, or reading it to students in other classes.

Some other aspects considered that had given a significant contribution to the students' enhancement during the teaching and learning process of writing descriptive essay particularly when implemented WPA were (1) clear instruction and explanation of doing the activities in every writing stage, (2) maximal guidance and control in applying the writing process, (3) the need of visual media related to the topic discussed and other supported media such as pictures, LCD, etc., (4) the need of vocabulary guide related to the topic discussed, (5) the more exercises of using guidelines in every writing stage, and (6) the way of grouping in doing the writing process.

\section{The Enhancement of the Students' Writing Skill}

The implementation of WPA with the proper model procedures developed can enhance the students' skill in writing a descriptive essay. The enhancement can be examined from the enhancements of the students' achievement in writing a descriptive essay and of their involvement in the writing activities during the implementation of WPA in the teaching and learning process.

The students' achievement in writing a descriptive essay enhanced is shown from the enhancement of the percentage of the students achieving the score greater than or equal to $C$ (56-70) of the range that lies from $0-100$ in Preliminary Study, Cycle I and II as shown in Figure 1. 


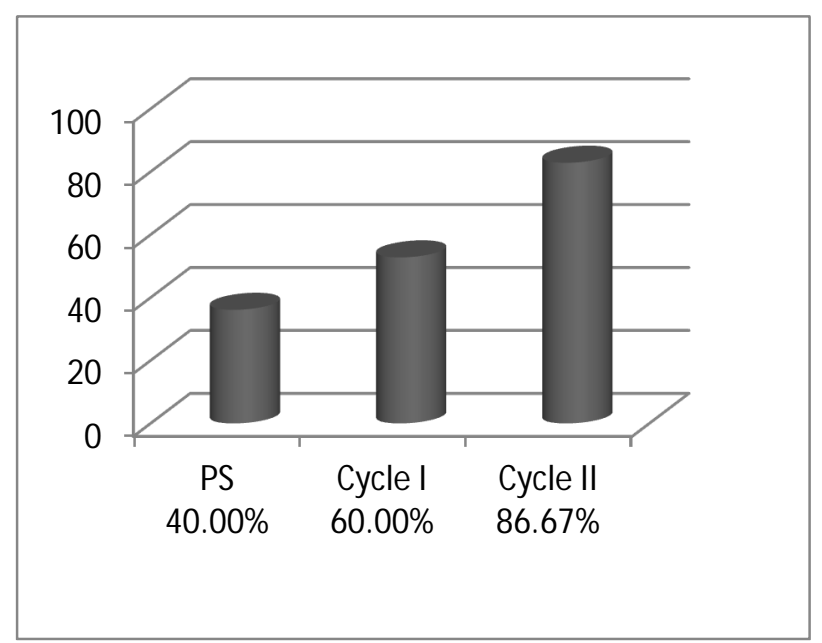

Figure 1. The Enhancement of the Percentage of the Students Achieving the Score $\geq$ C (56-70)

Figure 1 shows that the percentage of the students achieving the score greater than or equal to $C$ (56-70) in Preliminary Study was $40.00 \%$ (6 students of the class). It increased enough into $60.00 \% \quad$ (9 students of the class) in Cycle I. Meanwhile, in Cycle II it enhanced into $86.67 \%$ (13 students of the class). This was a slight enhancement.

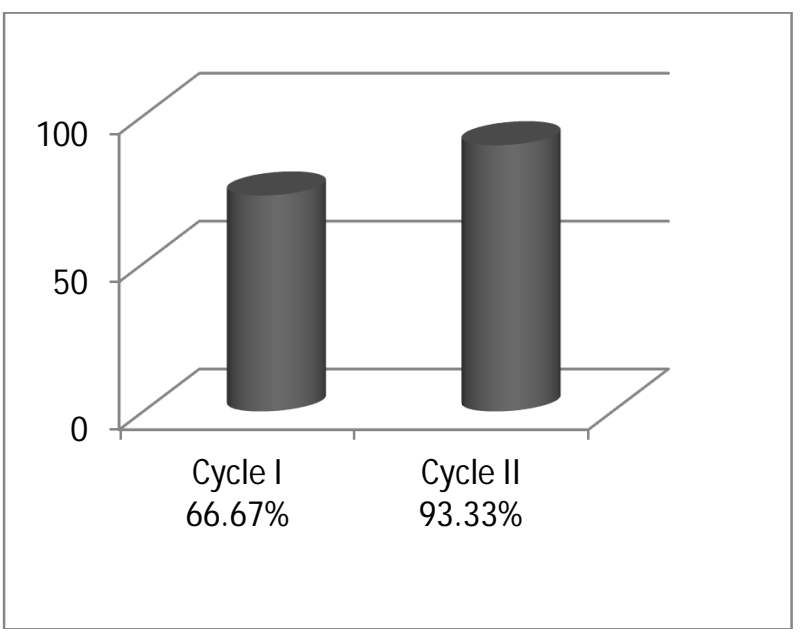

Figure 2. The Enhancement of the Students' Involvement in the Writing Activities
Dealing with the students' involvement in the writing activities during the implementation of WPA in the teaching and learning process, it is shown from the enhancement of the percentage of the students' involvement in the writing activities in every cycle. The enhancement of the students' involvement in the writing activities in Cycle I and II is shown in Figure 2.

Figure 2 shows that in Cycle I some students did not implement all activities seriously. Only $66.67 \%$ students (10 students of the class) were involved in the writing activities. Meanwhile, in Cycle II the students involved in the writing activities increased into $93.33 \%$ students (14 students of the class). They were actively involved in the writing activities.

\section{CONCLUSION}

After implementing WPA with the proper model procedures developed, the students' skill in writing a descriptive essay enhances. It is indicated by the enhancements of the percentage of the students achieving the score greater than or equal to $C$ (56-70) and of the percentage of their involvement in the writing activities during the implementation of WPA in Cycle I and II (Figure 1 and 2). The success of this study is in Cycle II. So, it needs long time to succeed in this study.

The enhancement of the students' skill in writing a descriptive essay can be reached but it should follow the proper model procedures of the implementation of WPA as follows: (1) telling students about the objectives of the lesson, (2) involving students in brainstorming activity utilizing pictures related to the topic discussed through LCD in order that 
they have background knowledge, (3) directing students in clustering activity before they write their first drafts, (4) giving and explaining a model of descriptive essay before they write their rough drafts, (5) providing students with models of the rough draft and guideline of doing drafting, revising and editing activities individually, (6) assigning students to work in their groups cooperatively equipped with vocabulary guide, (7) asking students to write their first drafts, (8) having a mini-conference to give suggestions and comments to revise their drafts, (9) conducting both self and peer editing in which students edit the mechanical aspects, and (10) having students read aloud their own final writings and their friends' final writings.

To follow up the conclusion, some suggestions are proposed to the English teachers/lecturers, students and future researchers. The English teachers/ecturers of Writing Course are recommended to employ the proper model procedures of implementation of WPA as one of the alternative strategies in their writing class because of the effectiveness of the strategy. The procedures proposed, however, need to agree with the students' characteristics and conditions. They have better develop their way of teaching related to the procedures of the implementation of WPA for the more appropriate application.

Regarding the implementation of WPA with the proper model procedures developed was effective and suitable to enhance the students' skill in writing essay, the students are suggested to apply it independently not only in the classroom but also outside wherever they are writing any type of essay. Finally, future researchers are recommended to conduct such kinds of research concerned with the implementation of WPA in English teaching applying the other kinds of essays such as narration, expository, process, comparison and contrast, etc., by considering the strength of the implementation of WPA as an approach in teaching writing.

\section{REFERENCES}

Brown, H.D. (2001). Teaching by Principles: An Interactive Approach to Language Pedagogy ( $2^{\text {nd }}$ ed.). New York: Addison Wesley Longman Inc.

Christenson, T.A. (2002). Supporting Struggling Writers in the Elementary Classroom. New York: The International Reading Association.

Cohen, A.D. (1994). Assessing Language Ability in the Classroom ( $2^{\text {nd }}$ ed.). Boston: Heinle and Heinle Publishers.

Dixon, C.N. \& Nessel, D. (1983). Language Experience Approach to Reading (Writing). London: Prentice-Hall.

Djiwandono, M. S. (2008). Tes Bahasa: Pegangan bagi Pengajar Bahasa. Jakarta: PT Indeks.

Gebhard, J.G. (2000). Teaching English as a Foreign or Second Language: A Teacher Self-Development and Methodology Guide. Ann Arbor: The University of Michigan Press.

Glencoe. (2001). Writer's Choice: Grammar and Composition Grade 6. New York: McGraw-Hill Companies.

Kemmis, S. \& McTaggart, R. (1992). The Action Research Planner ( $3^{\text {rd }}$ ed.). Victoria: Deakin University Press.

Leki, I. (1991). Twenty Years of Constructive Rhetoric: Text 
Analysis and Writing Pedagogies. TESOL Quarterly, 25(1), 123-43.

Mukminatien, N. (1991). Making a Writing Class Interesting. TEFLIN Journal: An EFL Journal in Indonesia, $4(2)$.

Ndanguru, H. (2008). The Implementation of Process-Writing Approach to Improve the Writing Ability of the Second Year Students of MTsN Lakudo.

Unpublished Thesis. Malang: State University of Malang.

Nunan, D. (1999). Second Language Teaching and Learning. Boston, Massachusetts: Heinle \& Heinle.

O'Malley, J. M. \& Pierce, L. V. (1996). Authentic Assessment for English Language Learners. Practical Approaches for teachers. Massachusetts: Addison - Wesley Publishing Company, Inc.

Onukwugha, U. (2007). The Four Cardinal Points of Any Good Writing: Expression, Content, Organization $\mathcal{E}$ Technical Accuracy. Ezine Articles.com. 28 Sep 2008: http://ezinearticles.com/?The-FourCardinal-Points-of-Any-GoodWriting:- (Accessed 2008, September $\left.29^{\text {th }}\right)$.
Raimes, A. (1983). Techniques in Teaching Writing. New York: Oxford University Press.

Roe, B. D., Stoodt, B. D. \& Burns, P. C. (1995). Secondary School Reading Instruction: The Content Areas (5 ${ }^{\text {th }}$ ed.). Boston: Houghton Mifflin Company.

Smalley, R. L., Reutten, M. K. \& Rishel, O. (2001). Refining Composition Skills: Rhetoric and Grammar for ESL Students. New York: Macmillan Publishing Company.

Stone, J.M. (1990). Cooperative Learning and Language Arts: A Multi-Structural Approach. California: Resources for Teachers.

Tompkins, G.E. \& Hoskisson, K. (1995). Language Arts: Content and Teaching Strategies. New York: Macmillan Publishing Company.

Tompkins, G.E. (1994). Teaching Writing: Balancing Process and Product. New York: Macmillan Publishing Company.

Vacca, R.T. \& Vacca, J.A.L. (1999). Content Area Reading: Literacy and Learning across the Curriculum (6 $6^{\text {th }}$ ed.). Boston: Addison-Weley Educational Publishers Inc. 